"Human resource practices as determinants of employees' intention to leave: a study from a selected South African institution"

\begin{tabular}{ll} 
AUTHORS & $\begin{array}{l}\text { Muleya D. } \\
\text { Hlanganipai Ngirande } \\
\text { Rachidi M.P. }\end{array}$ \\
& $\begin{array}{l}\text { Muleya D., Hlanganipai Ngirande and Rachidi M.P. (2016). Human resource } \\
\text { practices as determinants of employees' intention to leave: a study from a } \\
\text { selected South African institution. Investment Management and Financial } \\
\text { Innovations, } 13(3-2), 403-409 . \text { doi:10.21511/imfi.13(3-2).2016.13 }\end{array}$ \\
\hline DOI & http://dx.doi.org/10.21511/imfi.13(3-2).2016.13 \\
\hline RELEASED ON & Monday, 10 October 2016 \\
\hline JOURNAL & "Investment Management and Financial Innovations" \\
\hline FOUNDER & LLC "Consulting Publishing Company "Business Perspectives"
\end{tabular}

NUMBER OF REFERENCES

0

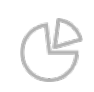

NUMBER OF FIGURES

0

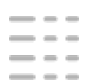

NUMBER OF TABLES

0

(C) The author(s) 2023. This publication is an open access article. 


\title{
Human resource practices as determinants of employees' Intention to leave: a study from a selected South African institution
}

\begin{abstract}
The success of higher education institutions worldwide lies in the quality of their employees. The study investigated the influence of human resource practices on academic staff members' intention to leave. The study which was conducted at a selected university in South Africa, consisted of $(n=35$ males $=85.7 \%$ and female $=14.3 \%)$ who completed a questionnaire on their perceptions of human resource practices on employees' intention to leave. Data was analyzed to determine the human resource practices which have significant influence on employees' intention to leave. Findings from the correlation analysis indicated a significant relationship between organizational culture, working conditions, remuneration, as well as remuneration administration, and employees' intention to leave.
\end{abstract}

Keywords: intention to leave, recruitment, organizational culture, remuneration, working conditions, organizational policy.

JEL Classification: J63, M12, J31, J81.

\section{Introduction}

People are the most important assets in any organization. Employees perform all key functions which result in the achievement of the vision of the organisation. The retention of employees is a concern in every organization, as it affects the al performance (Selesho \& Naile, 2014). The retention of high performing employees and keeping employees engaged helps to create and maintain competitive advantage (Stone, 2008). Organizations must consider retention as a critical element in order to succeed in talent management (Ngirande \& Musara, 2016).

According to Lockwood (2006), retention is defined as a process of implementing integrated strategies which are designed to increase productivity through developing improved processes for attracting, developing, retaining and utilizing people with the required skills and aptitude to meet current and future business needs. Talented employees are valuable and often irreplaceable. Organizations must ensure that they not only have the right people, at the right time, doing the right things, and at the right place, but also have the ability to retain them. In order for retention to be done effectively employers must identify, develop and promote their best performers, this may also assist in ensuring the survival and success of the organization (Ngobeni \& Bezuidenhout, 2011).

An organization must ensure that it has an effective human resource management strategy which is able to balance the cost of replacing employees who

(C) Muleya D., Ngirande H., Rachidi M.P., 2016.

Muleya D., Department of Human Resource Management \& Labor Relations, University of Venda, South Africa.

Hlanganipai Ngirande, Department of Human Resource Management \& Labor Relations, University of Venda, South Africa.

Rachidi M.P., Department of Human Resource Management, University of Venda, South Africa. leave against the cost of retaining those who stay (Kakar, Raziq \& Khan, 2015). An effective human resource management strategy will assist in minimizing employee turnover which would, then, mean that employees are being retained (Stone, 2008). Hence, it is important for an organization to retain and motivate its employees to make sure they are committed, competent and capable. The retention of one employee means one less person to be recruited, selected and trained by the organization (Selesho \& Naile, 2014).

According to Nel, Werner, Poisat, Sono, Du Plesis, Ngalo, Van Hoek and Botha (2014), the following determinants have an impact on employees' intention to leave organizational culture, organizational policy, remuneration and working conditions.

\section{Review of related literature}

Determinants of employees' intention to leave are, namely, organizational culture, remuneration, working conditions and organizational policy will be discussed.

\section{Organizational culture}

Organizational culture is defined as a set of values, beliefs and rules held by an organization (Nel et al., 2014). The retention of employees may vary from organization to organization. This variation in employee retention may be related to organizational culture values (Schein, 2010). The organization's culture frames how it deals with or handles the external environment. It also shows its consistency of mindset and provides a focus of identification through the core values and beliefs within the recruitment policy ( $\mathrm{Nel}$ et al., 2014).

The culture of the organization has impact on employees' intention to leave, and a positive workplace culture is very important for consistent improvement and it also ensures that employees are 
in a good place such that they would agree to give extra efforts for the organization (Das, Gupta \& Tommer, 2005). It is less difficult to retain employees who are committed to the organizationas they are likely to stay, because they want to (Lumley, Coetzee, Tladinyane \& Ferreira, 2011). Therefore, the organization's culture may determine an employee's decision on whether to stay or leave the organization.

On the other hand, negative workplace culture has negative impact on employees, as it leads to absenteeism, poor performance and turnover (Mowday, Porter \& Steers, 2013). An organization whose culture emphasises personal initiative and individual rewards would enhance an entrepreneurial norm whereby the organization does not offer a long - term security and the employees do not promise loyalty (Sinha, 2012). Such an organizational culture would result in high turnover, as employees would rather leave than stay.

\section{Remuneration and remuneration administration}

Remuneration is important to employees for satisfying their economic needs. If employees are not satisfied with their remuneration, this may impact on their behavior and attitudes. If employees are not satisfied with their remuneration, their level of commitment to the organization will decrease and may steer them towards leaving the organization (Singh \& Loncar, 2010). According to Phillips and Gully (2011), the level of remuneration that an organization is willing and able to invest in employees can both determine and be determined by its ability to hire people with the necessary competence. Higher education institutions worldwide are losing highly qualified academic staff to the [private sector and to other universities which are able to offer better benefit and rewards (Erasmus, Grobler \& Niekerk, 2015).

It is, therefore, important for university management to know how the remuneration or compensation they offer to certain positions compares with compensation for similar positions in other higher education institutions and other competitors. In addition, if competitors are known to remuneration more, the employers will need to use remunerationas leverage. However, if an organization is known as good to work for due to its training, work environment and compensation, then, the organization may be able to retain most of its employees than its competitors (Phillips \& Gully, 2011).

In a study among nurses by Steinmetz, De Vries and Tijdens (2014), it was found that employees who perceive that they are fairly paid are likely to stay in the organization for a long period whereas those who perceive that they are unfairly paid are likely to leave. Rajkaran and Mammen (2014) state that money is important in attracting, motivating and retaining employees and they also highlighted that skilled employees are achievement oriented and want their achievements to be rewarded with money. In addition, a study conducted by Chiboiwa, Samuel and Chipunza (2010) in a private medical company found that employees left their jobs or organizations as a result of poor reward system administration. In higher education sector, similar findings were revealed among senior academic staff members in South African higher learning institutions (Samuel \& Chipunza, 2013).

Remuneration administration refers to the manner in which an employee's remuneration is determined. In terms of higher education academic staff, their remuneration may be based on the administration of wages. According to applicable laws and the University's staff classification system. Depending on the manner in which their remuneration is administered, some employees may be satisfied and decide to stay with the organization or may be dissatisfied and choose to leave the organization (Phillips \& Gully, 2011). It is, therefore, important for employers to ensure that remuneration administration is done fairly.

\section{Working conditions}

Working conditions refer to the conditions under which employees have to work ( $\mathrm{Nel}$ et al., 2014). These working conditions may include factors such as safety and comfort of machinery, lighting, ventilation, disciplinary procedures and communication. An organization's working conditions might influence potential employees and is fundamental in attracting candidates with suitable credentials $(\mathrm{Du}$ Plesis, Frederick \& Goodwin, 2010). In addition, working conditions may also have an impact on an employee's decision to leave or stay in the organization.

Heath (2006) states that the quality of an employee's workplace environment has an impact on employee motivation and may affect his or her performance which might result in the retention of employees. Employees who are exposed to good working conditions are likely to perform well and remain in their organization. Schermerhorn, Hunt and Osborn (2005) state that good working conditions assist in the effective delivery of products and services. On the other hand, poor working conditions may lead to absenteeism, fatigue and employee turnover (Health, 2006).

\section{Organizational policy}

Organizational policies are a course of action or guidelines to be followed and to help to guide and determine present and future decisions ( $\mathrm{Nel}$ et al., 
2014). These organizational policies provide a description and understanding of the formal structure of the organization. An organization may have a policy on its human resources factors such as recruitment and selection, promotion, training and development, labor relations and remuneration among others. A recruitment policy which enables all vacancies to be filled by internal employees may reduce employee turnoveras employees would feel that they stand chances of being promoted through the filling of vacancies internally. Furthermore, in some organizations they consider seniority when filling up vacancies (Nel et al., 2014). This would also motivate employees who would be having a promotion opportunity and might result in less labor turnover.

\section{The concept of employee retention}

Employee retention is defined as the ability by an organization to retain its employees (Stone, 2008). It can also be viewed as an organization's ability to stop employees from leaving an organization or keeping the good employees (Huang, Lin \& Chuang, 2006). In today's dynamic environment quality employees create a competitive advantage for organizations thus creating a business case for retaining them. Employee retention must be carefully and effectively done so as to ensure that the organization does not lose its most valuable employees.

In a university setting, academic staff members' competence, commitment and capabilities determine efficiency, productivity, longevity, as well as growth and prestige of an institution. Their retention should thus be a priority for both human resources practitioners and management (Ajak, Oba \& Ekpo, 2014).

According to Eric, Lam, Charles \& Vimala (2012), employees may not leave an organization if they are satisfied with their working conditions, have good working relationships with their colleagues, receive competitive remuneration and operate in an conducive organizational culture. For example, academic staff may decide to leave an institution due to their remuneration dissatisfaction (Hong, Hao, Kumar, Ramedran \& Kadiresan, 2012). Mayer (2006) points out that most young employees are very mobile and would move from one organization to the other unlike the elderly employees.

Employers must as such realize that different age groups may be influenced to stay or leave by different factors. Elderly employees may leave because of inadequate retirement packages, while younger employees may leave for greener pastures related to promotion and new challenges among others. Moreover, Selesho and Naile (2014) state that, in order to retain academics, there has to be academic growth and a strong organizational policy, if these are available, then, most of the academic staff would remain in the organization. On the other hand, Naris and Ukpere (2010) state that employees may leave an organization due to poor working conditions, financial rewards and excessive workload among other factors. If employees have excessive workload and in addition to that feel that their working conditions and financial rewards are poor, they would leave the organization. In addition, employees may also leave the organizational if their beliefs, values and culture are in conflict to those of the organization (Selesho \& Naile, 2014).

A study conducted by Ghosh, Satyawadi, Prasad Joshi and Shadman (2013) revealed working conditions as the most influential factor which determined the employees' intention to quit. The results further revealed that compensation packages and location were also identified as the most significant factors influencing employee retention. However, in a study conducted by Sheridan (2008) in a banking sector on 800 employees, it was found that the organizational policy, organizational culture and working conditions have an impact on employee retention.

In addition, some universities in South Africa are under-resourced and this has an impact on the scholars concerned (HESA, 2011; Mouton, 2010). Previous research has stated that state and research funding of public universities has significantly deteriorated over the past two decades (De Villiers \& Steyn, 2009; Mouton, 2010). As a result, the work of academic staff has become more emotionally demanding (Bitzer, 2008). It is, therefore, important to conduct a study of this nature among academic staff so as to determine the human resource practices.

\section{Problem statement}

The success of any organization depends on the quality of human resource that it has. These quality employees can be a source of competitive advantage to the organization, a competitive advantage that gives an organization competitive edge over its competitors (Nel et al., 2014). The retention of employees who have high competitive value remains a major challenge in many organizations (Lumley et al., 2011). It is, therefore, this challenge that has prompted organizations to try and decrease turnover and increase the retention rates of key talent so as to improve an organization's competitive advantage (Erasmus et al., 2015). A number of studies related to employee retention have been done both locally and internationally; however, very few studies were done in the higher education sector (Biswas \& Varma, 2007; Sheridan, 2008). The studies which were done in higher education institutions invariably focused on employee retention and other non-human resources practices or variables (Ngobeni \& Bezuidenhout, 2011; Selesho \& Naile, 2014; Erasmus et al., 2015). Therefore, the study seeks to investigate the influence 
of specific human resource practices (remuneration, working conditions, organizational policy and organizational culture) as determinants of employees' intention to leave among academics at a selected South African higher education institution.

\section{Research objectives}

The study is guided by the following objective:

- To determine the influence of human resource practices (organizational culture, remuneration, working conditions and organizational policies) on academic staff member's intention to leave.

\section{Research hypotheses}

The study hypothesized that:
- H1: There is a significant relationship between organizational culture and employees' intention to leave.

- H2: There is a significant relationship between remuneration and employees' intention to leave.

- H3: There is a significant relationship between remuneration administration and employees' intention to leave.

- H4: There is a significant relationship between working conditions and employees' intention to leave.

- H5: There is a significant relationship between fair policy and employees' intention to leave.

- H6: There is a significant relationship between unfair policy and employees' intention to leave.

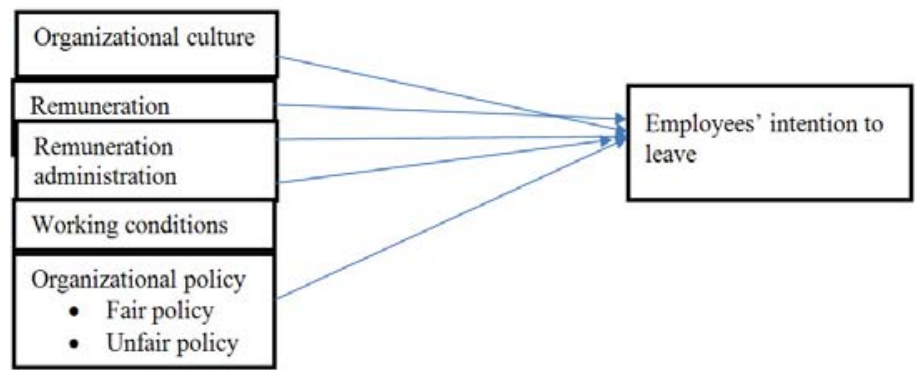

Fig. 1. Proposed model of the relationship between human resource practices (organizational culture, remuneration, working conditions and organizational policy and employees' intention to leave)

\section{Research methodology}

\section{Participants and sampling procedure}

A quantitative research design was used. The population of the study comprised of academics from the University of Venda. Using a stratified random sampling technique, the researchers drew a sample of 35 from 55 academics from the School of Management Sciences.

\section{Data collection}

A self-administered questionnaire was used. A selfdeveloped 15 item instrument answered on a 5-point Likert scale ranging from Strongly Agree (1) to Strongly Disagree (5) was used to measure the selected human resource practices. The determinants comprised of organizational culture (2), remuneration (2), working conditions (3) and organizational policy (3).Some of the items included are "this is a great organisation to work for", "I am likely to stay because of my recent remuneration raise", "my working conditions are pleasant" and "I may not leave this organization because the policy on remuneration is fair to all employees".

The Intention to leave questionnaire (Lyons, 1971) was used to determine the employees' intention to leave. It has 3 items and was answered using a 5point Likert scale. Examples of items included "I often think about quitting" and "I often think of changing my job".

\section{Research procedure}

Permission was granted from the University Research Directorate and a covering letter accompanied the questionnaire which assured participants of their anonymity and confidentiality.

\section{Reliability}

The measurement of reliability provides consistency in the measurement of variables. Cronbach's alpha coefficients were used to assess the internal consistency of the measuring instruments and items. Table 1 below shows the reliability coefficient alpha of all the constructs in this study ranging from $\alpha=-0.081$ (organizational policy) to $\alpha=0.841$ (intention to leave).

Table 1. Reliability of scales

\begin{tabular}{|l|c|c|}
\hline \multicolumn{1}{|c|}{ Scale } & Number of items & Cronbach alpha \\
\hline Organizational culture & 2 & 0.671 \\
\hline Remuneration & 2 & -0.081 \\
\hline Working conditions & 3 & 0.767 \\
\hline Organizational policy & 3 & 0.735 \\
\hline Intention to leave & 3 & 0.841 \\
\hline
\end{tabular}

\section{Data analysis}

The data were analyzed using Statistical Package for Social Sciences (SPSS) version 23. Descriptive statistics were used to describe the data collected in summary form. The correlation analysis was used to 
determine whether there is any association between intention to leave determinants (organizational culture, remuneration, working conditions and organizational policy) and employee retention. Multiple regression analysis was used to determine the most contributing human resource practice to employees' intention to leave the organization.

\section{Results and discussion}

\section{Demographic information}

The statistics in Table 2 show that among most of the participants $30(85.7 \%)$ were males, while females were $5(14.3 \%)$. The majority of the participants 13 (37.1\%) were aged between 31-39 years and only 2
(5.7\%) were above 60 years of age. All the participants who participated were black in race. The highest number of participants 30 (85.7\%) were married and only one participant was widowed $1(2.9 \%)$. Moreover, most of the participants had a masters' degree as their highest qualification 19 (54.3\%) followed by 12 (34.3\%) those who possess $\mathrm{PhD}$. The study also revealed that the majority of the participants $12(34.3 \%)$ have been in the organization for a period between 6-10 years, while $3(8.6 \%)$ of the participants have been in the organization for the longest time, for more than 15 years. Most of the participants in this research study were lecturers and senior lecturers $16(45.7 \%)$.

Table 2. Descriptive statistics

\begin{tabular}{|c|c|c|}
\hline Demographic variables & Frequency (f) & Percentage (\%) \\
\hline $\begin{array}{l}\text { Gender } \\
\text { Male } \\
\text { Female }\end{array}$ & $\begin{array}{c}30 \\
5\end{array}$ & $\begin{array}{l}85.7 \\
14.3 \\
\end{array}$ \\
\hline $\begin{array}{l}\text { Age } \\
\text { Below } 30 \\
31-39 \\
40-49 \\
50-59 \\
60 \text { and above }\end{array}$ & $\begin{array}{c}4 \\
13 \\
8 \\
8 \\
2 \\
\end{array}$ & $\begin{array}{c}11.4 \\
37.1 \\
22.9 \\
22.9 \\
5.7\end{array}$ \\
\hline $\begin{array}{l}\text { Race } \\
\text { Black }\end{array}$ & 35 & 100 \\
\hline $\begin{array}{l}\text { Marital status } \\
\text { Single } \\
\text { Married } \\
\text { Widowed }\end{array}$ & $\begin{array}{c}4 \\
30 \\
1\end{array}$ & $\begin{array}{c}11.4 \\
85.7 \\
2.9\end{array}$ \\
\hline $\begin{array}{l}\text { Highest qualification } \\
\text { Honours degree } \\
\text { Master's degree } \\
\text { PhD degree }\end{array}$ & $\begin{array}{c}4 \\
19 \\
12\end{array}$ & $\begin{array}{l}11.4 \\
54.3 \\
34.3 \\
\end{array}$ \\
\hline $\begin{array}{l}\text { Tenure } \\
\text { Below } 1 \text { year } \\
2-5 \text { years } \\
6-10 \text { years } \\
11-15 \text { years } \\
15 \text { years and above }\end{array}$ & $\begin{array}{c}8 \\
10 \\
12 \\
2 \\
3\end{array}$ & $\begin{array}{c}22.9 \\
28.6 \\
34.3 \\
5.7 \\
8.6\end{array}$ \\
\hline $\begin{array}{l}\text { Position and level } \\
\text { Junior lecturer } \\
\text { Lecturer } \\
\text { Senior lecturer } \\
\text { Professor }\end{array}$ & $\begin{array}{c}1 \\
16 \\
16 \\
2\end{array}$ & $\begin{array}{c}2.9 \\
45.7 \\
45.7 \\
5.7\end{array}$ \\
\hline Total & 35 & 100 \\
\hline
\end{tabular}

Hypotheses testing: Relationship between human resource practices and employee intention to leave.
The Pearson - product correlations allowed the researchers to identify the direction and strength of the relationship between each of the variables.

Table 3. Relationships between human resource practices and intention to leave

\begin{tabular}{|l|c|c|c|c|c|c|c|c|c|}
\hline & $\mathrm{M}$ & $\mathrm{SD}$ & 1 & 2 & 3 & 4 & 5 & 6 & 7 \\
\hline 1.Organizational culture & 3.629 & 0.860 & & & & & & & \\
\hline 2. Remuneration & 2.300 & 1.016 & 0.241 & & & & & & \\
\hline 3. Remuneration administration & 2.471 & 1.071 & -0.156 & -0.134 & & & & & \\
\hline 4. Working conditions & 8.829 & 1.948 & $0.435^{* *}$ & 0.331 & -0.009 & & & & \\
\hline 5. Fair policy & 2.614 & 0.956 & 0.089 & $0.517^{\star *}$ & 0.169 & 0.295 & & & \\
\hline 6. Unfair policy & 2.743 & 0.491 & -0.163 & -0.062 & 0.154 & 0.060 & $-0.375^{\star *}$ & & \\
\hline 7. Intention to leave & 7.886 & 3.411 & $-0.541^{* *}$ & $-0.414^{* \star}$ & $0.563^{\star *}$ & $-0.375^{*}$ & $0.000^{* *}$ & -0.150 & \\
\hline
\end{tabular}

Notes: ** Correlation is significant at the 0.01 level ( 2 tailed). * Correlation is significant at the 0.05 level $(2$ tailed). 
As shown in Table 3, the results show a significant negative relationship between organizational culture and intention to leave $(r=-0.541 ; p=0.001)$. This means that, as organizational culture improves the employees' intention to leave the organization decreases. It can, thus, be concluded that there is a relationship between organizational culture and intention to leave. The results also show that there is a significant negative relationship between remuneration and intention to leave $(r=-0.414$; $p=0.013)$. This means that as remuneration increases, the employees may feel reluctant to leave the organization. We, therefore, conclude that there is a relationship between remuneration and intention to leave. In addition, the results show a significant positive relationship between remuneration administration and intention to leave $(r=0.563$; $p=0.000)$. This stipulates that as remuneration administration is done fairly or improves, the employees may not leave the organization.

Moreover, the results also show that there is a significant negative relationship between working conditions and intention to leave $(r=-0.375$; $p=0.026)$. This shows that as the working conditions improve the employees' intention to leave decreases. The results show that there is relationship between fair policy and intention to leave and a no relationship between unfair policy and intention to leave.

Multiple regression analysis: Human resource practices and employees' intention to leave the organization

The results from the analysis of variance in Table 4 below show that some variables in the model have a significant influence on the employees' intention to leave $(F=10.441 ; p=0.00)$. Findings from the regression analysis indicate a significant effect on organizational culture and intention to leave $(\beta=.0 .42 ; p \leq 0.002)$. These findings are consistent with those by Das, Gupta and Tommer (2005), as well as Schein (2010) who reported that the culture of an organization has an impact on employees' intention to leave. They stated that improved organizational culture reduces employees' intention to leave an organization. In addition, remuneration administration $(\beta=.0 .522 ; p \leq 0.000)$ variables positively predict employee intention to leave. Results also show that unfair organizational policy $(\beta=.0 .319 ; p \leq 0.017)$ variable positively predict employee intention to leave. In the light of the ongoing result, the hypotheses are accepted. However, results show that remuneration $(\beta=.0 .218 ; p \geq 0.118)$, fair policy $(\beta=.0 .033$; $p \geq 0.830)$ and working conditions $(\beta=.0 .087$; $p \geq 0.501$ ) do not predict employee intention to leave the organization. Therefore, from the results, we fail to accept the hypothesis.

Table 4. Regression of human resource practices and intention to leave

\begin{tabular}{|l|c|l|c|c|}
\hline $\begin{array}{l}\text { Dependent variable: } \\
\text { intention to leave }\end{array}$ & $\beta$ & & Std. err. & $p$-value \\
\hline $\begin{array}{l}\text { Organizational } \\
\text { culture }\end{array}$ & -0.419 & & 0.488 & 0.002 \\
\hline Remuneration & -0.218 & & 0.453 & 0.118 \\
\hline $\begin{array}{l}\text { Remuneration } \\
\text { administration }\end{array}$ & 0.522 & & 0.369 & 0.000 \\
\hline Working conditions & -0.087 & & 0.223 & 0.501 \\
\hline Fair policy & -0.033 & & 0.537 & 0.830 \\
\hline Unfair policy & -0.319 & & 0.877 & 0.017 \\
\hline$R^{2}$ & & 0.691 & & \\
\hline$F$ & & 10.441 & & \\
\hline
\end{tabular}

\section{Limitations}

The sample was small and focused on employees in only one higher education institution, thus, reducing the power of this study and the potential to generalize the results to other occupational groups and industries. Despite this limitation, the results of this study show potential for the analysis of the determinants of employees' intention to leave. It is recommended that further studies be undertaken involving other occupational groups in order to address the limitations of the present study.

\section{Conclusion}

The study revealed that there is a relationship between organizational culture and employee retention. The improvement in the culture of an organization limits the employees'intention to leave the organization. In addition, a relationship was also found between working conditions and intention to leave. It was revealed that as an organization's working conditions improve, employees intention to leave decreases. Thus, in order for employees to remain with the organization, the organizational culture and working conditions must be improved, their needs must be met. The study also showed that unfair policies may lead to staff turnover.

\section{References}

1. Ajak, U.E., Oba, A.N. \& Expo, T.E. (2014). Enriching higher education curriculum to meet the challenges of $21^{\text {st }}$ Century in Nigeria, Journal of Educational and Social Research, 4(3), pp. 37-43.

2. Bitzer, E.M. (2008). The professoriate in South Africa: Potentially risking status inflation, South African Journal of Higher Education, 22, pp. 265-281.

3. Chiboiwa, M.A., Samuel, M. \& Chipunza, C. (2010). An examination of employee retention strategy in a private organisation in Zimbabwe, African Journal of Business Management, 4 (10), pp. 2103-2109. 
4. De Villiers, A.P. \& Steyn, A.G.W. (2009). Effect of changes in state funding of higher education output in South Africa: 1986-2007, South African Journal of Higher Education, 22, pp. 43-68.

5. Dessler, G. (2005). Dessler, G., Griffith, D.J. \& Walker, L. (2007). Human Resource Management. (3rd ed.). Pearson Education. Australia.

6. Du Plesis, A. J., Frederick, H. \& Goodwin, C. (2010). The importance of training and education for New Zealand entrepreneurs: Some empirical evidence. Sunshine Coast, Australia.

7. Erasmus, B. J., Grobler, A. \& Van Niekerk, M. (2015). Employee retention in a higher education institution: an organisational development perspective, Progression, 37(2), pp. 33-63.

8. Eric, C.H., Lam, Z. H., Charles, R. \& Vimala, K. (2012). An effectiveness of human resource management practices on employee retention in institution of higher learning: A regression analysis, International Journal of Business Research and Management, 3(2), pp. 60-79.

9. Ghosh, P., Satyawadi, R., Prasad Joshi, J. \& Shadman, M. (2013). Who stays with you? Factors predicting employees' intention to stay, International Journal of al Analysis, 21(3), pp. 288-312.

10. HESA. (2011). A generation of growth: Proposal for a national program to develop the next generation of academics for South African higher education. Pretoria: University of South Africa.

11. Hong, E.N.C., Hao, L.Z., Kumar, R., Ramedran, C. \& Kadiresan, V. (2012). An effectiveness of human resource management practices on employee retention in institute of higher learning: A regression analysis, International Journal of Business Research and Management, 3(2), pp. 60-79.

12. Kakar, P., Raziq, A. \& Khan, F. (2015). Impact of Human Resource Management Practices on Employee Retention: A Case of Banking Sector in Quetta Baluchistan, Journal of Management Info, 5(1), pp. 97-119.

13. Lockwood, N.R. (2006). Talent management: Driver for organizational success, Journal of Human Resource Management, 51 (6), pp. 23-26.

14. Lumley, E.J., Coetzee, M., Tladinyane, R. \& Ferreira, N. (2011). Exploring the job satisfaction and organisational commitment of employees in the information technology environment, Southern African Business Review, 15(1), pp. $100-118$.

15. Mouton, J. (2010). African experience with collaborative graduate programs. Research report. Stellenbosch: University of Stellenbosch.

16. Mowday, R.T., Porter, L.W. \& Steers, R.M. (2013). Employee - linkages: The psychology of commitment, absenteeism, and turnover. Academic press.

17. Naris, S.N. \& Ukpere, W.I. (2010). Developing a retention strategy for qualified staff at the Polytechnic of Namibia, African Journal of Business Management, 4 (6), pp. 1078-1084.

18. Nel, P., Werner, A., Du Plessis, A., Ngalo, O., Poisat, P., Sono, T., Van Hoek, L. \& Botha, C. (2011). Human Resource Management (8th ed.). Oxford University Press.

19. Ngirande, H. \& Musara, M. (2016). Training and development for career management and talent development in wholesale and retail industry in South Africa, Journal of Psychology in Africa, 26(2), pp. 164-166.

20. Ngobeni, E.K. \& Bezuidenhout, A. (2011). Engaging employees for improved retention at a higher education institution in South Africa, African Journal of Business Management, 5(23), pp. 9961-9970.

21. Phillips, J. \& Gully, C. (2011). Managing employee retention. USA: Butterworth.

22. Rajkaran, S. \& Mammen, K.J. (2014). Identifying Key Performance Indicators for Academic Departments in a Comprehensive University through a Consensus-based Approach: A South African Case Study, Journal of Sociology and Anthropology, 5(3), pp. 283-294.

23. Samuel, M.O. \& Chipunza, C. (2013). Attrition and retention of senior academics at institutions of higher learning in South Africa: The strategies, complexities and realities, Journal of Social Science, 35(2), pp. 97-109.

24. Schein, E.H. (2010). Organizational culture and leadership $\left(4^{\text {th }}\right.$ ed.). New York: John Wiley \& Sons, Inc.

25. Schmermerhorn, J.R., Hunt, S. \& Osborn, C. (2005). Organizational Behaviour (7th ed.). New York: John Wiley \& Sons, Inc.

26. Selesho, J.M. \& Naile, I. (2014). Academic staff retention as a human resource factor: University perspective, The International Business \& Economics Research Journal, 13(2), p. 295.

27. Sheridan, J.E. (2008). The configuration of employee retention practices in multinational corporations' foreign subsidiaries, International Business Review, 12 (2), pp. 225-233.

28. Singh, P. \& Loncar, N. (2010). Remuneration satisfaction. Job satisfaction and turnover intent, Industrial relations, 65 (3), pp. 470-490.

29. Sinha, C. (2012). Factors affecting employee retention: A Comparative Analysis of two Organizations from Heavy Engineering Industry, European Journal of Business and Management, 4 (3), pp. 145-162.

30. Steinmetz, S., de Vries, D.H. \& Tijdens, K.G. (2014). Should l stay or should I go? The impact of working time and wages on retention in the health workforce.

31. Stone, R.J. (2008). Human Resource Management (5th ed.). Australia: John Wiley and Sons. 